\title{
Historical merchant courts and their renovation
}

\author{
Anastasia Bredikhina ${ }^{1, *}$ and Ekaterina Vozniak $^{1}$ \\ ${ }^{1}$ Saint-Petersburg State University of Architecture and Civil Engineering, 190005, 4, 2 \\ Krasnoarmeyskaya st., Saint Petersburg, Russia
}

\begin{abstract}
The study of the methods of renovation of living merchant courts and systematization of them will allow you to select the most optimal options for their modern use. The purpose of the work: studying the variety of methods of renovation of merchant courts, identifying their positive and negative sides. Methods: classification by volume-spatial and volume-planning characteristics, comparative analysis of the historical and modern state of the studied buildings. Results: various approaches to renovation of merchant courts were studied, domestic and foreign experience of adaptation was considered. Their historical and cultural value and the need to preserve them have been proved. The most interesting examples in various directions are given. The positive and negative sides of different approaches are considered. Conclusions are made about the possibilities of modern use of merchant courts. Optimal solutions for adaptation are proposed depending on the volume-planning structure of the building under consideration. Recommendations are given for the preferred functional content (priority is given to mixed functions).
\end{abstract}

\section{Introduction}

Merchant court (or a historic Russian term "Gostiny Dvor") is one of the oldest type of commercial buildings, widely spread in Russia and it is a typical Russian phenomenon at the junction of European and Asian architecture. An important problem is the search for ways of renovating them. The purpose of the work is to select the most optimal ways of modern use of these buildings. Merchant courtyard consist of separate small cells that are combined in various ways and can have a linear, closed or semi-closed appearance. In accordance with the urban development plans of cities, they were located mainly in the center. In terms of planning characteristics, merchant courts are similar to shopping malls, but until the end of the XVIII century they had a difference in functional purpose. Today, the relevance of these buildings is not only in their historical value. Their Central location makes them promising objects for modern use.

\footnotetext{
* Corresponding author: elle0072008@yandex.ru
} 


\subsection{Subject, tasks and methods}

The study examines the largest and most significant merchant courts in Russia. A lot of work on the history of merchant courts was done by E. V. Gusarova (Gusarova, 2009). This article focuses on the development of classification of buildings of this type and the search for the most successful examples of their modern renovation.

To do this, the studied buildings were divided by volume and planning characteristics. This made it possible to choose the main directions of renovation for each individual type. The selection was carried out on the basis of a study of the current state of individual merchant courts. For the most objective assessment, we took into account: the overall view of the building, attendance, involvement in the modern life of the city, the interaction of the object with the environment, reviews of buildings made by professional experts and ordinary visitors. To expand the understanding of modern methods of renovation, commercial buildings with similar planning and spatial structure abroad were considered.

\subsection{Research results and discussion}

Merchant courts, according to various researchers, appeared in Russia in the XVI-XVII centuries (Gusarova, 2009), some sources mention the XII century (Kamochkin, 2015; Shaskolsky, 1965). Their specific feature was that they were intended for wholesale trade of visiting merchants. In addition to retail stores, this type of living area included living quarters, warehouses, and in some cases even prayer rooms. The latter is especially typical for the merchant courts (commercial courtyards) in Astrakhan (figure 1).

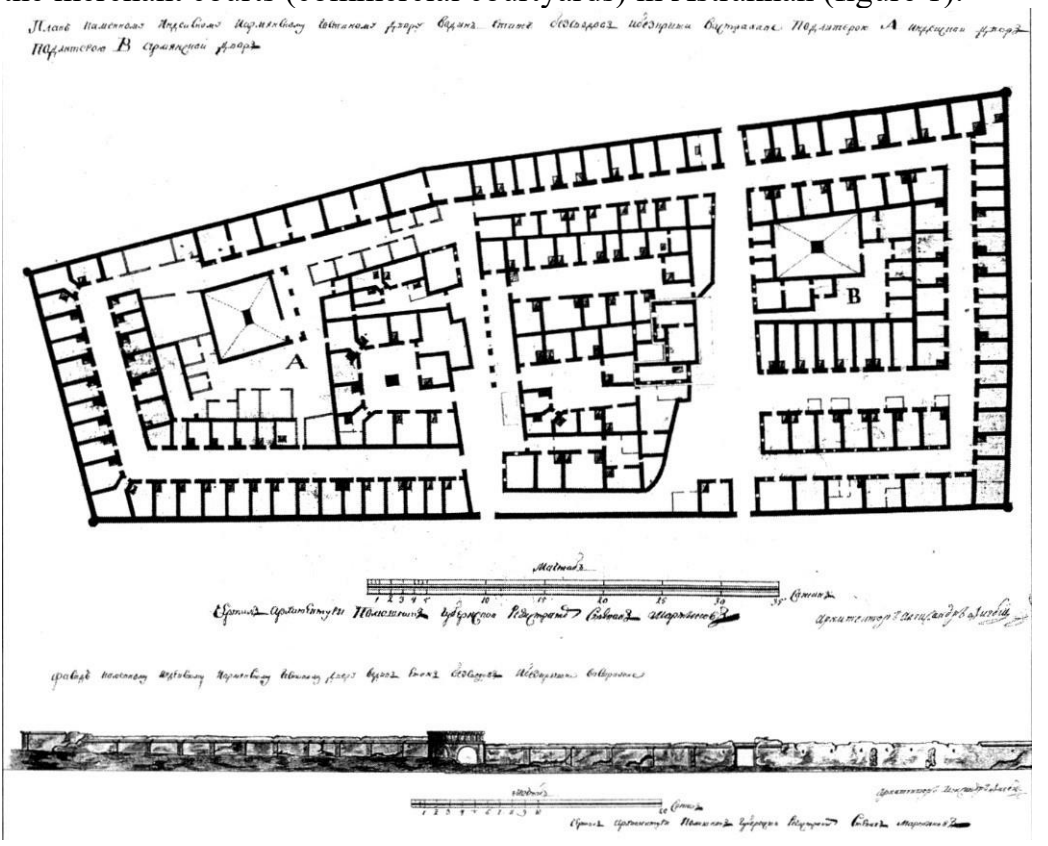

Fig. 1. Plan and facade of the "Foreign" Gostiny Dvor in Astrakhan. Fixing drawing: the second half of the XVIII century. Architect Alexander Digby. Russian state historical archive. St.Petersburg

Early living merchant courts were fortified closed fortresses and were built, as a rule, outside the walls of the Kremlin (Gusarova, 2009, Shaskolsky, 1965). This was due to several factors. First, it allowed to control the trade process, suppressing prohibited retail trade among foreign merchants and protecting the interests of local merchants. Second, this tradition has been strengthened since the time when foreign traders were engaged in piracy 
and robbery (Kulisher, 2004). Among other things, such spatial organization allowed to protect the goods of the merchants. Among the remaining living merchant courtyards of this type can be called Tobolsk and, despite the strong restructuring and loss of parts of the buildings, Arkhangelsk.

Merchant courts received a new stage of development at the end of the XVIII beginning of the XIX century (Kamochkin, 2015). Such buildings were built mainly in large cities. This type was formed during the abolition of internal customs duties and the release of trade activities from class restrictions. These are the usual buildings with shops facing the street, united by a passage gallery, arcade or colonnade. There already was the same retail trade, both local and visiting merchants, and residential premises had been abolished. The characteristic closed structure is preserved in the plan, but there are exceptions ("Gostiny Dvor" in Pushkin, ("Gostiny Dvor" in Krasnoyarsk). Not all cellular commercial buildings with a closed structure were called "Gostiny Dvor", for example, in St. Petersburg there are a number of buildings that, despite their shape, are called markets and shopping malls. These include Nikolsky rows, Yamsky market, Round market, and others (Sementsov, 2007). Therefore, we can say that the main commercial building of the city was called the "Gostiny Dvor" until the middle of the XIX century.

In addition to single commercial buildings, there were ensembles. Thus, the Bolshoy Gostiny Dvor complex in Saint Petersburg consists of two closed rings of buildings and the building of the Management Committee. Both rings are built in different architectural styles. If the outer ring is an example of early classicism (Wozniak, 2015; Wozniak, 2014; Wozniak, 2017), the inner ring is built in eclectic forms. Another major ensemble is the Gostiny Dvor building complex in Kaluga, which consists of 14 buildings made in Russian Gothic ( pseudo- Gothic).

A distinctive feature of the trade was that in each row (or sometimes this was called "lines"), one type of product was sold, for which the row was named. Fires that affected wooden shops forced merchants to choose stone buildings, which have survived to our time (Bogdanov, 2001; Sementsov, 2006). Retail units in Russia were small in size. Foreign travelers remarked: "these Shops are small and sometimes of poor quality; it is impossible to compare them with the ones in Amsterdam, because we would have to admit that one Amsterdam shop can be used to carve out ten or more Moscow ones" (Kulisher, 2003).

Classification of shopping malls and living merchant yards.

Trading cells could be blocked in various ways, but perhaps one of the most popular was a closed location. With such a planning system or ensemble building, a chapel was often arranged in the courtyard. This technique has its roots in the period when trade was arranged on the square in front of the Church or near it (Sementsov, 2007; Blondel, 1774). Thus, merchants and buyers were under divine protection, where they were not to be cheated or robbed. However, such chapels are almost not preserved.

Since living merchant yards (which acquired the characteristic features of shopping malls over time ) were actively built up to the middle of the XIX century, until they were replaced by other, more modern types of buildings, they have a fairly long history, during which they managed to change several styles (Bernd, 2011).

Thus, the classification of these buildings can be carried out in two directions: style and space-planning.

Cellular buildings are divided according to their style characteristics as follows:

* wooden architecture: XII-XVII C. (not preserved);

* Russian style, fortress architecture (XVII-Con. XVIII): Gostiny Dvor in Tobolsk;

* classicism (con. XVIII-XIX C.): Bolshoy Gostiny Dvor in Saint Petersburg, Gostiny Dvor in Pushkin, Gostiny Dvor in Kronstadt;

* eclecticism (con. XIX century): Gostiny Dvor in Yeysk, Gostiny Dvor in Kazan, Gostiny Dvor in Ufa, Gostiny Dvor in Kaluga. 
According to spatial characteristics, living merchant yards can be divided into ensembles and single buildings. Single, in turn, according to the volume-planning characteristics are divided into closed and semi-closed (less often linear).

\subsection{Merchant yards and shopping arcades abroad. Examples of their renovation}

Shopping malls and guest courtyards abroad were different from the ones we were used to in Russia. First, the shops were larger, and second, in many situations, the front building, which had a short end facade facing the street, assumed the development of the building deep into the block.

In Stockholm, until 1904, there were shopping malls with a planning structure similar to the Russian ones. They were long and linear in shape, located in the very center of Stockholm, on Adolf Gustav square, but they were not restored after demolition.

Notable shopping malls in the city of Oslo (Basarene Kirkeristen), built around the Oslo Cathedral. They close the block on three sides forming a semi-enclosed space inside. Now they are located various shops and cafes, which in warm times occupy in particular the territory of the courtyard.

In Venice, there are two palaces that served as trading yards for visiting merchants: Fondaco dei Tedeschi (German court), Fondaco dei Turque (Turkish court). Like merchant yards in Russia, these buildings have a closed planning structure with an internal courtyard.

When adapting for modern use, two different approaches were applied to the palaces: with the introduction of modern structural elements (the dome of the ceiling) and without them.

The Turkish courtyard is used as a natural history Museum, but its interior remains open. The last major restoration of this Palace took place in the second half of the XIX century.

The Fondaco dei Tedeschi was renovated in 2016 under the direction of Rem Koolhaas and his architectural firm OMA. The building is adapted for a shopping center, the courtyard is closed, and there is an observation deck on the roof (figure 2). It is worth noting that, despite the active, modern approach to the reconstruction of this building, the work was done carefully enough, the glass dome does not violate existing panoramas of the city, the historical frame of the building is not affected, in the center of the atrium an ancient Venetian well is preserved.

In Cracow, Poland, and Ypres, Belgium, there are impressive buildings of cloth rows (chambers of clothiers). They also consisted of blocks of shops with an exit on the first floor. In the course of numerous reconstructions, the building of cloth rows in Krakow received a long hall covered with arched vaults. Both these buildings went different ways of adaptation. Ypres Cloth Hall is a home to a Museum dedicated to the events of the World War I. The building in Cracow received a mixed function: retail shops and a restaurant on the first floor and the "Gallery of Polish art of the XIX century" on the top.

\subsection{The basic ways of renovating of terraced trade buildings}

Considering the examples of the modern existence of various shopping arcades in Russia and abroad, we see that there are quite a lot of possible ways to renovate them (Wozniak, 2018; Mouilleseaux, 1988). When choosing the most suitable, in each case, you should take into account some of their features, which may limit the range of possible solutions. 


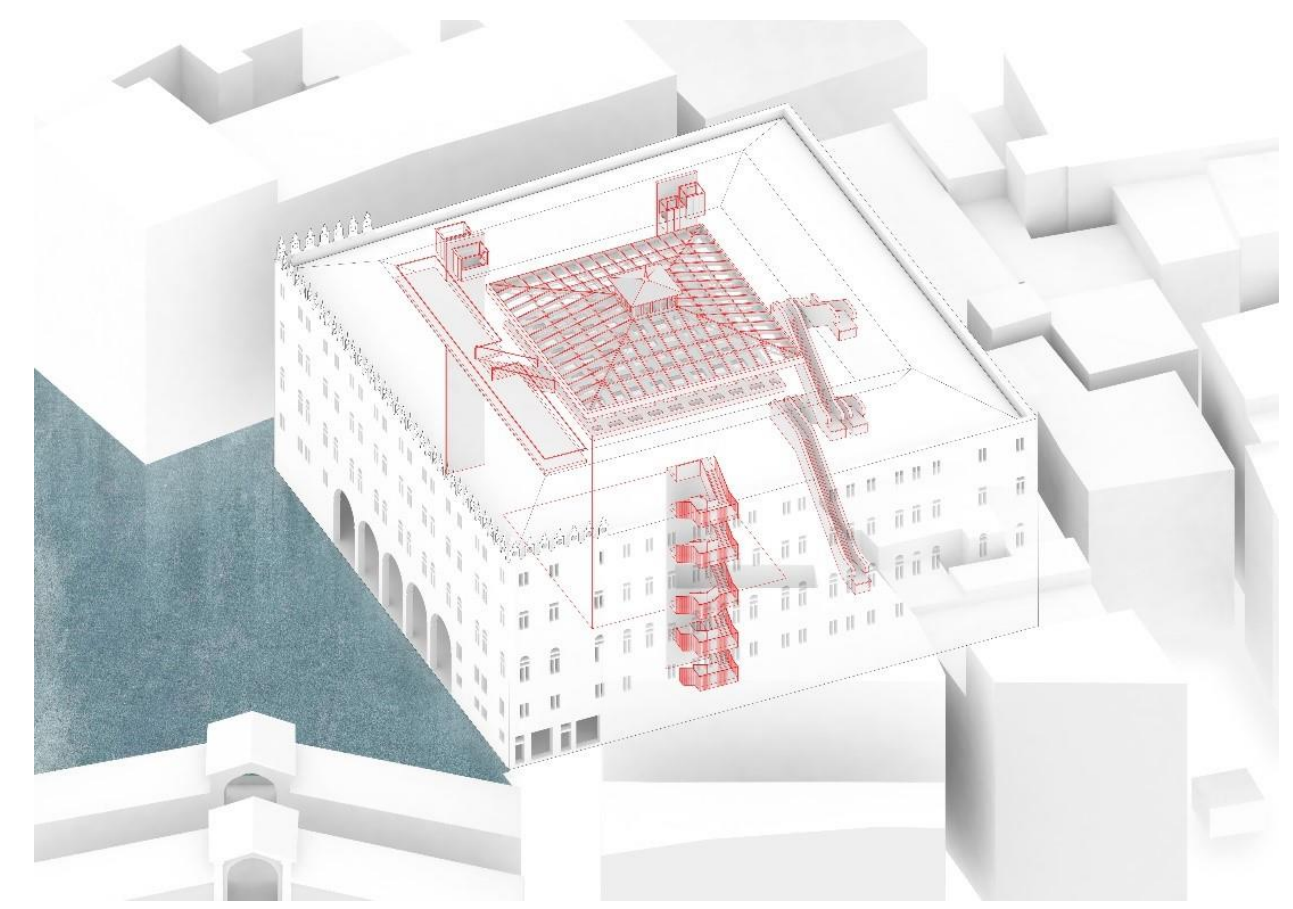

Fig. 2. Reconstruction of the Fondaco dei Tedeschi. Modern extensions are highlighted in red.

The very first step is to decide on the functional content of the building. The degree of investment attractiveness of the object and how actively it will interact with the environment is decided at this stage already. When making a decision, many factors should be taken into account, the most important of which, perhaps, are the functional zone of the city and the urban development situation around it. It may seem most correct to maintain the original trading function, but this is not always the case. Analyzing modern solutions for adaptation, it is clear that a successful solution is often the use of a mixed type of functions, or the use of related, such as the device of small cafes, bistros or coffee shops.

When selecting planning solutions for shopping malls, there is often a question about returning the cellular layout. The advantages of this solution include the preservation of the authentic look of buildings, reaching a large number of possible tenants, in fact, high competition, in which the buyer will have a wide range of best quality goods that will surely attract people there. With this layout, in addition to the retail one, the office function of the object is also acceptable. To the disadvantages of this approach can be attributed the relatively small area that can be rented out, as well as the destruction of the usual way for local residents to interact with the building.

Preserving the gallery layout can be considered as "preserving historical layers". This solution allows you to place stores of any size in the building, and also offers an interesting scenario of the visitor's movement, when he smoothly moves from one point of sale to another, without perceiving clear boundaries, in other words, the building works on the principle of a department store. This variant is preserved in most shopping arcades and merchant yards, including Gostiny Dvor in Kronstadt, Bolshoy Gostiny Dvor in St. Petersburg, and others. Another advantage is the ability to avoid moving along an open street in the cold season. The disadvantage may be the organization of a constant flow of visitors passing through the gallery, which can prevent a comfortable introduction to the product in a separate store. 
The option of combining both layouts would allow to expand the range of offers, both for renting stores and for buyers. The use of partitions that are easy to dismantle would allow to adjust the size of the rented space depending on the needs of the store. Proper zoning of the building would make it possible to regulate the flow of visitors.

The most difficult stage is the decision about the volume-spatial composition. This is especially true for closed and semi-closed objects. Several approaches can be distinguished here:

- use of internal space for economic purposes (internal Parking, loading and unloading area, warehouse);

- organization of additional retail space (with the installation of small non-capital buildings);

- public green space (small Park).

It is logical to use the courtyard space for economic purposes. This is how the courtyard of the Yamsky market (Saint Petersburg) is now used.

The decision to organize additional retail space may be fraught with turning the courtyard into a "bazaar". To prevent this, retail spaces must be equipped in the same style that will be combined with the image of the main building. It is also necessary to regulate the closeness of installation of new shops/kiosks, optimally their total area should not be more than $40 \%$ of the total area of internal space for closed objects, and no more than $50 \%$ for semi-closed objects (Wozniak, Makhova, 2017; Hunt, 2007). A good example of the installation of new objects in the courtyard space is the Gostiny Dvor in Kronstadt, in Pushkin, the shopping building became an illustration of the transformation of the interior space into the "bazaar". In this direction, the Gostiny Dvor in Pushkin was renovated in 2009 (Bureau Shapovalov and sons) (figures 3, 4). In principle, the initially good idea of the creation of landscaping with a recreation area and the construction of additional trade pavilions was disfigured by the permission of trade from tents and stalls, which turned the Tsarskoye Selo Gostiny Dvor into a regular "bazaar".



Fig. 3. Renovation project of the Tsarskoye Selo Gostiny Dvor, 2009.

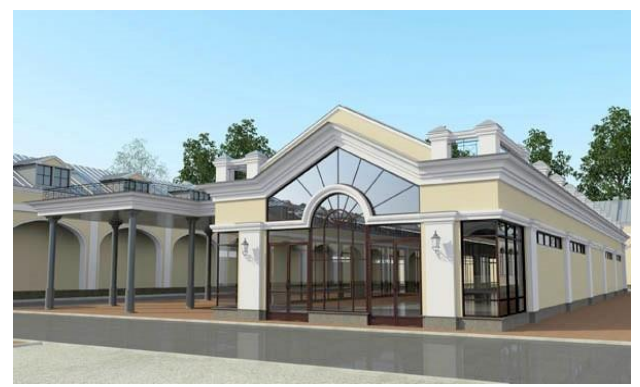

Fig. 4. Renovation project of the Tsarskoye Selo Gostiny Dvor, 2009. 
In general, the main directions of renovation can be divided into 3 large categories: planning, spatial and functional. Planning solutions include, respectively, various solutions for the planning structure, such as recreating/preserving the cellular layout, focusing on preserving the gallery layout, or a variety of combinations thereof. The planning directions also include the adaptation of buildings to modern sanitary and hygienic requirements.

Solutions about functional content are selected based on the current urban development situation, the characteristics of a modern functional zone, and additional analyses, including SWOT analysis, which allow you to choose not only a safe for building, but also a commercially attractive function. In practice, due to the presence of several tenants and the variety of requirements for modern retail facilities, preference goes to mixed types of functions.

As mentioned earlier, the most complex are space-planning solutions. A good, and perhaps the safest, option is to green the interior space (Wozniak, Makhova, 2017). This will give the city a new recreational area, which is especially important for large cities, will not entail controversial decisions in relation to the building, and will contribute to the promotion of the object. This method was chosen by Studio 44 for the renovation of the Bolshoy Gostiny Dvor in Saint Petersburg, both in an early and later project, and it was also used in the restoration of the Nikolsky rows (Saint Petersburg) (figure 5).

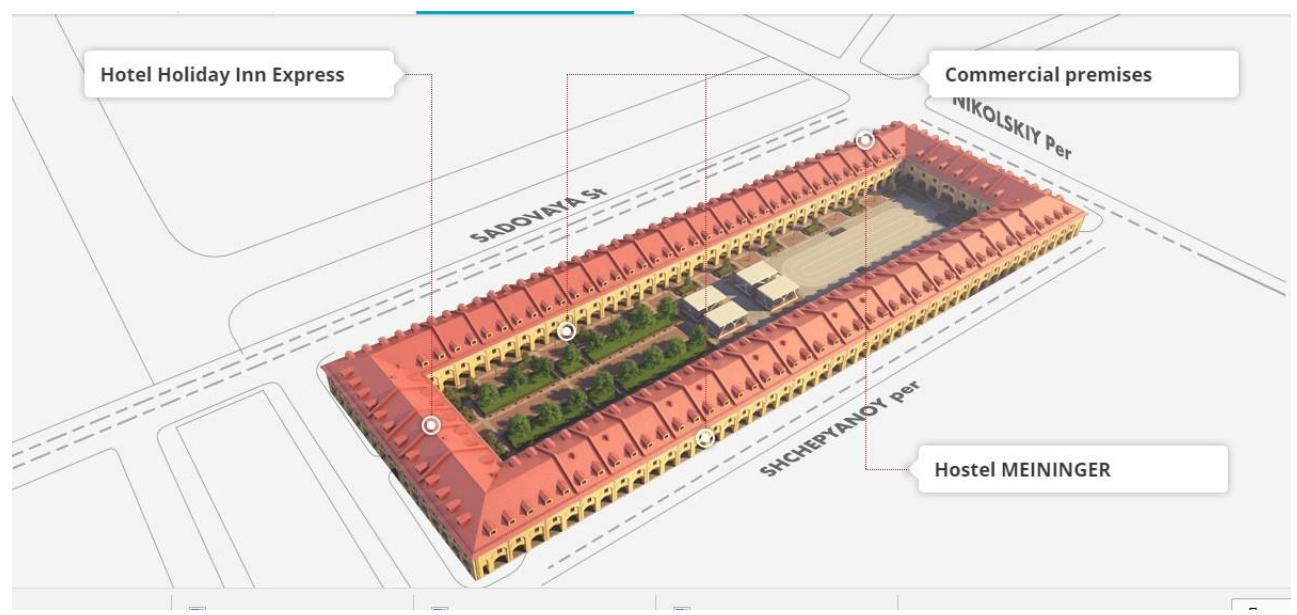

Fig. 5. Renovation of the market rows of Nicholas in St. Petersburg. Architectural Bureau " Litejnaya chast' - 91" by Raphael Dayanov.

Now the trend of overlapping internal spaces with translucent structures is quite popular. This solution can turn the building into a modern shopping center with a large bright atrium, expand the possibilities of adaptation, organize additional retail/recreational/exhibition space. This is a very modern solution that is actively used in Russia and abroad. However, this solution has significant disadvantages. First, the installed ceilings will give an additional load on the load-bearing and enclosing structures of the building. Secondly, the use of such a solution can significantly distort the appearance of the object, which will not only lose the "spirit of the place", but also distort the characteristic panoramas of the city. An example of a complete overlap of the courtyard was implemented in the Old Gostiny Dvor in Moscow, however, this decision was sharply criticized by citizens and experts in the field of architecture. A similar implementation in Gostiny Dvor in Ufa looks more successful. The option of partially covering the internal space of the Bolshoi Gostiny Dvor in St. Petersburg was considered in an early project of Studio 44. 
To avoid this, it is necessary to conduct a preliminary landscape and visual analysis of the surrounding area of the object and assess the possible impact of this decision. This analysis also determines the maximum allowable height of the projected ceiling.

An interesting alternative to this method of renovation was offered by several architectural studios when choosing the concept of renovation of the Gostiny Dvor in Kaluga. The essence of the method is to support the floor not on the walls of the object, but on its own supports. This way you will get a transparent canopy, which can always be dismantled without causing damage to the building. Of course, in this case, you will not be able to create a warm interior, but it can save you from adverse weather conditions. In the case of the Kaluga Gostiny Dvor, one of the variants developed by Moscow-based company LLC "Upravlenye K" is an example of careful attention to the features of the monument being restored. In their version, the overlap is selected gable, creating smaller segments in contrast to the domed, which more organically fits into the existing environment. The metal frame also repeats the neo-Gothic motifs of the architecture of the ensemble itself.

A frequent technique dictated by the acute shortage of parking spaces is the creation of underground parking. Almost every conceptual renovation project at the development stage has this solution, but it is never implemented in practice. This is primarily due to the danger to the building, the cost and difficulty of practical implementation. Therefore, the decision to create an underground parking is not the most successful.

\section{Conclusions}

As we can see, living merchant yards have a fairly high potential for possible use and a wide range of solutions used in their adaptation. All this, as well as the specifics of placement, allows them to meet modern requirements and be promising for use by objects.

In the process of renovation, it is preferable to use a mixed type of functions with a predominance of commercial ones for living rooms. The most frequently supplemented function is public catering (cafes, fast food restaurants, coffee shops, etc.).

Renovation decisions should be applied individually, based on the degree of preservation, the planned nature of use and the preservation of historical and cultural significance. When implementing spatial solutions, it is necessary to rely on data from landscape and visual analysis.

For different spatial structures, the following solutions are optimal: for linear volumes of buildings-mainly preserving the historical layout with adaptation to modern sanitary and hygienic requirements (functional and planning direction); semi - enclosed buildings development of internal space, landscaping, landscaping, the possibility of organizing seasonal shopping and fair spaces; closed buildings-the same as for semi-enclosed, plus a solution for overlapping (full or partial) internal space.

\section{References}

1. I. A. Bogdanov, Bolshoy Gostiny Dvor in St. Petersburg. Series: Three centuries of Petersburg (SPb. : Art, 2001)

2. V._Murgul, Procedia Engineering, 117, 808-818 (2015) https://doi.org/10.1016/j.proeng.2015.08.145

3. E. R. Wozniak, MGSU bulletin 12, 13-24 (2015)

4. E. R. Wozniak, Modern problems of science and education 6, 18-25 (2014)

5. E. R. Wozniak, Modern problems of science and education 1, 22-26 (2017)

6. E. R. Wozniak, T. D. Makhova, Success of modern science 5(2), 125-129 (2017) 
7. E. V. Gusarova, Astrakhan finds: History, architecture, urban planning of Astrakhan XVI-XVIII centuries. According to documents from the collections of St. Petersburg (SPb.: Nestor-Istoriya, 2009)

8. G. A. Kamochkin, Yaroslavl pedagogical Bulletin, 1(1), 122-127 (2015)

9. I. M. Kulisher, History of Russian trade and industry (Chelyabinsk: Sotsium, 2003).

10. I. M. Kulisher, History of economic life in Western Europe: in 2 vol. 9th ed. Vol. 1. (Chelyabinsk: Sotsium, 2004).

11. S. V. Sementsov, Industrial and civil construction 9, 37-38 (2007)

12. S. V. Sementsov, Bulletin of civil engineers 2(7), 15-20 (2006)

13. I. P. Shaskolsky, Scandinavian collection. Tallinn 10, 83-107 (1965)

14. J. F. Blondel, J-F. Bastide, L'Homme du monde éclairé par les arts : T. 1-2 (Ŕ Amsterdam-Paris : chez Monory, 1774)

15. E. Bernd, Architectural Theory. Taschen, 848 p. (2011).

16. L. Hunt, Th. R. Martin, B. H. Rosenwein, The Making of the West : Peoples and Cultures : A Concise History : Volume II : Since 1340. R Second Edition (Ŕ Boston : Bedford/St. Martin's, 2007)

17. A. J. Mouilleseaux, J. P. Mouilleseaux, Les Architectes de la liberté (Ŕ Paris : Gallimard, 1988) 